\title{
Deshabandu Eng. A.N.S. Kulasinghe (1919-2006)
}

Deshabandu Eng. A.N.S. Kulasinghe, who was one of the most distinguished engineers to have served our

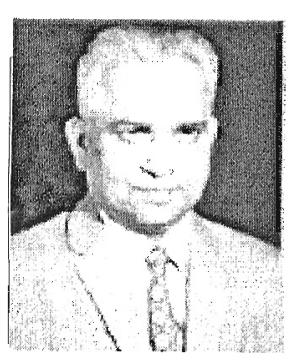
country during the last several decades, passed away on 14 February 2006. He spent most of his productive years in Sri Lanka, as Engineer, Scientist, Technologist, Teacher and Mentor of remarkable intellectual breadth. He was 87 at the time of his death. His death deprived the Sri Lankan scientific community of one of the most influential Engineers.

The engineering career of A.N.S. Kulasinghe spans 65 years. Much has been said and written about this great engineer and his achievements, but little is known about what made him so successful and that was his positive attitudes.

Born to a middle class family in rural Sri Lanka, Eng. Kulasinghe lost his mother at the very young age of four. He had his secondary education at Maris Stella College, Negombo and St. Benedict's College, Colombo. In 1938, he passed the London Matriculation Examination, securing a First Division, which enabled him to join the B.Sc(Eng.) (London) course at the Ceylon Technical College on an entrance scholarship. Due to the Second World War in 1940s, his studies were disrupted, but later in 1958 he completed the B.Sc(Eng.) Hons.(London) as an external candidate. In the same year, he was admitted as a Fellow of the Institution of Civil Engineers, London and Fellow of the Institution of Mechanical Engineers, London.

Eng. Kulasinghe started his engineering career in 1940 by joining the Ceylon Hydro-electric Scheme, Norton Bridge, as Technical Assistant to the Chief Resident Engineer. In 1944, he joined the Colombo Port Commission (CPC) as a Junior Assistant Harbour Engineer. Among his substantial contributions to the
$\mathrm{CPC}$ in the areas of civil and mechanical engineering, are the initiatives taken in developing laboratory facilities and modern construction methods such as pre-stressed concrete, concrete shell folded plate structures and piling techniques. He was promoted as the Chief Engineer in 1963 and became the Port Commissioner in 1968.

Eng. Kulasinghe also served as the Founder Chairman and General Manager of the State Engineering Corporation (SEC) of Sri Lanka for the period 19621971. During this period he led a group of brilliant young engineers who later formed the nuclei of civil and mechanical engineering in this country. He provided leadership to many of the major engineering projects in the country undertaken by the SEC.

He left the CPC in 1972 and served as a UN consultant in Malaysia during the period 1972-1977. Upon his return to Sri Lanka in 1978, he was appointed the Chairman of the National Engineering Research and Development Centre (NERDC) of Sri Lanka. For the next sixteen years, he provided invaluable leadership to NERDC in making pioneering contributions in many areas, such as solar energy, wood gasification and biogas, alternative energy and renewable substitutes for diesel. He has many patents and peer-reviewed publications to his credit. His personal contribution in the area of low cost housing (e.g. introduction of pre-cast, pre-stressed floor system etc.) will remain in the hearts of Sri Lankans in the years to come.

The Central Engineering Consultancy Bureau (CECB) was established in 1978 with Eng. Kulasinghe as the Chairman, to implement the accelerated Mahaweli Programme. During his Chairmanship until 1996, the $\mathrm{CECB}$ was involved in construction of the Victoria, Kotmale, Maduru Oya, Randenigala and Rantambe dams along with other structures such as power houses.

He was always ready to learn from his juniors if and when the necessity arose. He never felt insecure 
when it came to the latest technologies, and always had the "can-do" attitude. He firmly believed that the local engineers are capable of performing on par with any foreign counterparts.

Mentioned above are only a few highlights of his illustrious engineering career. Apart from these he has served the country in many other capacities viz. Chairman, National Science Council, Sri Lanka (1968); President, Institution of Engineers, Sri Lanka (1969); General President, Sri Lanka Association for the Advancement of Science (1970); Chairman, Bureau of Ceylon Standards (1978); Founder President, Association of Consulting Engineers, Sri Lanka (1982); President, National Academy of Sciences (1987); Additional Director General, National Building Research Organization (1996) etc.

He was a Fellow of several professional and academic bodies including Institution of Civil Engineers, London (1958); Institution of Mechanical Engineers, London (1958); Institution of Engineers, Sri Lanka (1960); Institution of Engineers, India (1960); Royal Institution of Naval Architects (1969) and the National Academy of Sciences, Sri Lanka (1975).

Eng. Kulasinghe received the National Honours "Vidya Jyothi Class I" (1986) and "Deshabandu" (2005). $\mathrm{He}$ was conferred the degree of Doctor of Science (Honoris Causa) by the University of Moratuwa (1979) and more recently, by the University of Peradeniya (2005). He was also conferred the degree of Doctor of
Engineering (Honoris Causa) by the Open University of Sri Lanka (2000).

Despite all his great achievements, Eng. Kulasinghe remained a modest man. He lived a simple and unostentatious life, and therefore his needs were moderate and material wealth was not important to him.

Eng. Kulasinghe was fond of music and enjoyed playing the Thabla and Dilruba. For him, music was an avenue for relieving his work-life stress and a source of relaxation. As a young child, he even fabricated a Dilruba himself. He was an able junior inventor and made an impulse turbine to harness the power from a small waterfall. He was an avid reader, which helped him to be knowledgeable in modern sciences and engineering. These attributes made him a complete man.

His remarkable contributions to the advancement of engineering and technology earned him a reputation as one of Sri Lanka's foremost scientists. His death has left a deep void in the scientific community and will always be remembered with deep gratitude.

NOTE: This appreciation was prepared based on information provided by Prof. S.B.S. Abeyakoon, Dean of the Faculty of Engineering, University of Peradeniya and Eng. Jayantha Ranatunga, President of the Institute of Engineers, Sri Lanka (IESL) and Chairman, NERD Centre.

- Editorial Office - 